\title{
Correction to: English as a medium of instruction (EMI) in computing undergraduate programs
}

\section{Munassir Alhamami ${ }^{1}$ (])}

Published online: 13 August 2021

(c) Springer Science+Business Media, LLC, part of Springer Nature 2021

\section{Correction to: Education and Information Technologies https://doi.org/10.1007/s10639-021-10637-6}

In the version of this article originally published, the Acknowledgements, Disclosure statement and Funding information were missing.

The original article has been corrected.

Acknowledgements The author extends his appreciation to the Deanship of Scientific Research at King Khalid University for funding this work through General Research Project under grant number (G.R.P$80-41)$.

Funding This work was supported by King Khalid University [grant number G.R.P- 80 -41].

Publisher's note Springer Nature remains neutral with regard to jurisdictional claims in published maps and institutional affiliations.

The original article can be found online at https://doi.org/10.1007/s10639-021-10637-6.

\section{Munassir Alhamami}

munassir7@gmail.com

1 King Khalid University, Abha, Saudi Arabia 